Nowoczesne Systemy Zarządzania

Zeszyt 12 (2017), nr 4 (październik-grudzień)

ISSN 1896-9380, s. 157-165

Modern Management Systems

Volume 12 (2017), No. 4 (October-December)

ISSN 1896-9380, pp. 157-165
Instytut Organizacji i Zarządzania

Wydział Cybernetyki

Wojskowa Akademia Techniczna

w Warszawie

Institute of Organization and Management

Faculty of Cybernetics

Military University of Technology

\title{
Zarządzanie ryzykiem na rynku walutowym Forex
}

\section{Risk management in the Forex market}

\author{
Hubert Zaborowski \\ Wojskowa Akademia Techniczna
}

\begin{abstract}
Abstrakt. Forex jest największym rynkiem finansowym na świecie. Szacowane dzienne obroty w kwietniu 2013 r. wynosiły około 5,3 biliona dolarów amerykańskich. Forex dzięki swoim cechom wyróżnia się na tle innych rynków i przyciąga miliony inwestorów na całym świecie. Jednocześnie należy podkreślić, że jest to bardzo trudny rynek i zanim przystąpi się do inwestowania, dobrze jest zdobyć jak najwięcej wiedzy w tym zakresie. W artykule skupię się na istocie Forexu oraz odpowiem na pytanie, jak można uchronić się przed utratą pieniędzy, skutecznie zarządzając ryzykiem na tym rynku finansowym.
\end{abstract}

Słowa kluczowe: Forex, rynek walutowy, ryzyko, zarządzanie.

Abstract: Forex is the largest financial market in the world. Estimated daily turnover in April 2013 was approximately $\$ 5.3$ trillion. Forex is distinguished by its features in comparison with other markets and attracts millions of investors around the world. At the same time, it is a very difficult market, and before investing, it is good to get as much knowledge as possible. In this article I will focus on the essence of Forex and will answer the question of how you can prevent yourself from losing money effectively managing the Forex market risk.

Keywords: forex, currency market, risk, management.

\section{Wstęp}

Forex dawniej był domeną funduszy hedgingowych, dużych banków, międzynarodowych korporacji, jak również największych inwestorów prowadzących interesy na całym świecie. W ostatnich latach doszło do wielu zmian w tym obszarze. Wraz w rozwojem Internetu możliwość aktywnego uczestnictwa w Forexie uzyskało znacznie szersze grono. Obecnie dziesiątki tysięcy osób na całym świecie rozpoczynają przygodę z Forexem i odkrywają wszelkie wyzwania, jakie im stawia 
rynek wymiany walut. Forex jest jednym z tych rynków, gdzie można szybko zarobić ogromne pieniądze, ale również w ciągu kilku chwil strącić całą fortunę. W artykule chciałbym przybliżyć czytelnikowi istotę Forexu - to jak funkcjonuje oraz przykładowe sposoby zarządzania ryzykiem.

Artykuł ma charakter teoretyczny i składa się z dwóch części:

1. istota Forexu;

2. zarządzanie ryzykiem.

\section{Istota Forexu}

Forex jest największym międzynarodowym rynkiem walutowym, wyróżniającym się największą płynnością oraz dynamiką na świecie. Handel na tym rynku zasadniczo opiera się na spekulacji wartością jednej waluty w stosunku do drugiej. Spekulacja, z jaką mamy do czynienia, jest jednoznaczna, podobna do tej, która zachodzi podczas zakupu akcji na giełdzie lub innego rodzaju papieru wartościowego. U podstaw leży nadzieja na osiągnięcie zysków ze sprzedaży waloru po wyższej cenie, niż został on zakupiony. Jednak ze względu na przedmiot spekulacji na Forexie, jakim są waluty różnych krajów, można dojść do wniosku, że handel na rynku walutowym polega na spekulacji czynnikami wpływającymi na wartość waluty oraz dynamiką rynku (Galant, 2012, s. 33).

\subsection{Zasady funkcjonowania}

Rynki walutowe różnią się od rynków giełdowych swoją specyfiką. Podstawową cechą jest decentralizacja. Notowania walut odbywają się bez określonej kontroli centralnej instytucji. Centra finansowe rozmieszczone są na całym świecie, a handel pomiędzy uczestnikami rynku przebiega praktycznie nieustannie przez 24 godziny na dobę w robocze dni tygodnia. Aktywność rynku zmienia się wraz z upływem doby, przenosząc się z każdą godziną coraz bardziej na zachód - od Azji po USA. Wspomniana wcześniej decentralizacja sprawia, że rynek przyjmuje charakter globalny. Rozwój technologii powoduje zmniejszenie znaczenia lokalizacji geograficznej uczestników rynku. Dzięki temu handel przebiega efektywniej, sprawniej oraz przy mniejszych kosztach transakcyjnych (Kochan, 2006, s. 15-16).

Z punktu widzenia polskiego inwestora typowy dzień notowań zaczyna się w nocy od sesji azjatyckiej. W dalszej kolejności do handlu przyłączają się rynki finansowe z Oceanii, Japonii oraz Chin. Rynek europejski rozpoczyna swoją działalność nad ranem czasu warszawskiego. Pomiędzy godziną 14 a 15 czasu warszawskiego na rynku pojawiają się w większej liczbie inwestorzy amerykańscy, u których właśnie rozpoczyna się dzień. Z chwilą zamknięcia się rynku amerykańskiego zaczyna się sesja w Azji. W ten sposób tworzy się 24-godzinny cykl na rynku 
walutowym. Notowania w godzinach łączenia się poszczególnych rynków często mają interesujący przebieg. To właśnie wtedy występuje największa aktywność inwestorów oraz wyraźne wzrosty zmienności notowań. W warszawskiej strefie czasowej można obserwować gwałtowne wahania kursów między godziną 8 i 10, ze względu na otwarcie się rynku europejskiego. Kolejna fala zmian kursów może nastąpić pomiędzy godziną 14 a 15, gdy włącza się rynek USA. To właśnie w tych godzinach publikowana jest największa liczba danych makroekonomicznych, na które inwestorzy mogę reagować w żywiołowy sposób. Nierzadko sporą zmienność na rynku przynosi początek sesji azjatyckiej, zwłaszcza podczas otwarcia rynku w poniedziałek, co może być spowodowane wystąpieniem istotnych wydarzeń w czasie trwania weekendu. Duża zmienność kursów może oznaczać dla inwestora szybkie zyski lub straty. Oczywiście przedstawiony schemat ma jedynie charakter orientacyjny. Z powodu dużej liczby zaangażowanych uczestników na rynku oraz ze względu na emocje, które nimi rządzą, trudno szukać sztywnego schematu, jakim będą się kierowali inwestorzy (Kochan, 2006, s. 19).

Tabela 1. Czas trwania sesji handlowych w poszczególnych regionach świata

\begin{tabular}{|c|c|c|c|c|c|}
\hline \multirow{2}{*}{ Region } & \multirow{2}{*}{ Obszar } & \multicolumn{2}{|c|}{ Czas zimowy } & \multicolumn{2}{c|}{ Czas letni } \\
\cline { 3 - 6 } Azja & Początek sesji & Koniec sesji & Początek sesji & Koniec sesji \\
\cline { 2 - 6 } & $\begin{array}{c}\text { Tokio } \\
\text { Singkong, }\end{array}$ & 1.00 & 9.00 & 1.00 & 9.00 \\
\hline \multirow{3}{*}{ Europa } & $\begin{array}{c}\text { Frankfurt, } \\
\text { Zurych, Paryż }\end{array}$ & 7.00 & 10.00 & 2.00 & 10.00 \\
\cline { 2 - 6 } & Londyn & 8.00 & 15.00 & 5.00 & 13.00 \\
\hline \multirow{2}{*}{ Ameryka } & Nowy York & 14.00 & 22.00 & 13.00 & 21.00 \\
\cline { 2 - 6 } & Chicago & 15.00 & 23.00 & 14.00 & 22.00 \\
\hline \multirow{2}{*}{ Oceania } & Wellington & 22.00 & 6.00 & 22.00 & 6.00 \\
\cline { 2 - 6 } & Sidney & 23.00 & 7.00 & 23.00 & 7.00 \\
\hline
\end{tabular}

Źródło: opracowanie własne na podstawie: Kochan, 2006, s. 21

\subsection{Uczestnicy rynku}

Największą i najbardziej aktywną grupę uczestników na rynku stanowią największe instytucje finansowe w postaci banków komercyjnych oraz inwestycyjnych. Biorą one udział bezpośrednio w obrocie walutami na rynku międzybankowym. Instytucje tego typu zawierają transakcje zarówno w swoim interesie, jak również na rachunek korporacji, rządów oraz innych instytucji finansowych. Przez długi czas możliwość korzystania z Forexu miały jedynie instytucje finansowe, jednak 
na skutek rozwoju Internetu możliwość spekulowania uzyskały również osoby fizyczne, które aktualnie stanowią drugą grupę pod względem udziału w rynku (najlepszeplatformyforex.pl, 2014).

\subsection{Dźwignia finansowa}

Dźwignia finansowa na Forexie jest narzędziem umożliwiającym optymalne wykorzystanie kapitału. Jeżeli wysokość dźwigni wynosi 10 : 1, oznacza to, że dysponując kapitałem w wysokości 1000 USD, można kontrolować pozycję wartą nawet 10000 USD Przeciętny poziom dźwigni, jaki oferują internetowi brokerzy, waha się w przedziale od $100: 1$ do nawet $500: 1$ w stosunku do wpłaconego depozytu. Wykorzystanie dźwigni jest bardzo istotną cechą rynku Forex, ze względu na to, że umożliwia inwestorom posiadającym mniejszą ilość kapitału uczestnictwo w rynku, w którym normalnie nie mogliby brać udziału. Lewar daje możliwość zarabiania na niewielkich wahaniach kursów walut i maksymalizuje zyski, jednocześnie działa w drugą stronę - źle wykorzystany maksymalizuje straty.

Poniżej znajduje się przykład zastosowania dźwigni na standardowym rachunku z depozytem w wysokości 5000 USD oraz przy dźwigni $100: 1$.

Wykorzystanie w pełni dźwigni daje możliwość kontrolowania pozycji o wielkości 500000 USD Otwierając pozycję USD/JPY po kursie $120 \mathrm{z}$ maksymalną dźwignią, każda zmiana o jedną jednostkę (pips) ma wartość ok. 40 USD [(500 000 USD × 0,01)/120,00 = 41,67 USD]. Para USD/JPY często w ciągu dnia potrafi zmieniać swoją wartość o 50-100 pipsów. Zatem źle oszacowana prognoza może w jeden dzień przynieść stratę rzędu 2000 USD do 4000 USD, czyli odpowiednio od $40 \%$ do $80 \%$ depozytu. Wyliczenia mają jedynie charakter poglądowy w celu zobrazowania funkcjonowania dźwigni (Galant, 2012, s. 269).

\subsection{Depozyt zabezpieczający}

Otwarcie pozycji wymaga przeznaczenia części kapitału na depozyt zabezpieczający. Jeżeli przykładowo broker określił obowiązkowy minimalny stały depozyt na poziomie $50 \%$, oznacza to, że co najmniej połowa początkowego depozytu musi stale występować na rachunku. Przy korzystaniu z dźwigni na poziomie $100: 1$, pozycji wynoszącej 100000 USD oraz z depozytem $50 \%$ kwota minimalna, która musi się znajdować na rachunku, wyniesie 500 USD [(100 000 USD/100) x 0,5 = 500 USD]. W przypadku gdy wartość rezerwy spadnie choćby na chwilę poniżej 500 USD, broker ma prawo zamknąć pozycję (Galant, 2012, s. 270).

Wymagania dotyczące minimalnego depozytu różnią się w zależności od typów kont oraz od brokera. Odmienne są także procedury dotyczące zamykania pozycji. W niektórych przypadkach zamykane są wszystkie pozycje, nawet te przynoszące zyski, 
a w innych zamykana jest jedynie pozycja przynosząca najwięcej strat. Mechanizm dźwigni działa w dwie strony i tak jak pozwala zarabiać na niewielkich wzrostach kursów, sprawia również, że niewielkie spadki mogą przynieść duże straty (Galant, 2012, s. 270).

\subsection{Czynniki mające wpływ na rynek walutowy}

Raporty zawierające różnego rodzaju dane makroekonomiczne stanowią najistotniejszy czynnik mający wpływ na sytuację rynku walutowego. Na podstawnie tych informacji podejmowane są decyzje inwestycyjne, zarówno przez osoby fizyczne, jak również przez osoby mające wpływ na kształt polityki monetarnej. Z perspektywy inwestora raporty gospodarcze wprowadzają rynki w ruch oraz stymulują zmiany kursów. Do najważniejszych wskaźników makroekonomicznych można zaliczyć (Stolarczyk, 2015, s. 11):

- Stopy procentowe - mają one istotny wpływ na kursy walut. Jeżeli są na niskim poziomie, pobudzają gospodarkę - tani kapitał zachęca do brania kredytów, przez co wzrasta poziom konsumpcji oraz inwestycji. Natomiast wysokie stopy procentowe skłaniają do oszczędzania, ponieważ podnoszą koszty kredytów i w konsekwencji zmniejszają poziom inwestycji. Stopy procentowe określają też kierunek transferu pieniądza na skalę globalną. Wynika to z oczekiwań inwestorów co do poziomu stopy zwrotu. Jeżeli przykładowo w Polsce oprocentowanie lokat jest na poziomie 2\%, a w Szwajcarii oprocentowanie depozytów we frankach wynosi 7\%, racjonalnym posunięciem jest kupno franków i sprzedaż złotówek, w konsekwencji czego kurs CHF/PLN będzie wzrastał (Money.pl, 2013).

- Inflacja - mierzona jest jako tempo wzrostu cen oraz stanowi istotny element wpływający na wahanie kursu walutowego. Zazwyczaj waluty krajów o niskim i stabilnym poziomie inflacji wskazują wzrostowy kierunek. Spowodowane jest to wzrostem siły nabywczej w odniesieniu do innych walut. Natomiast w krajach, w których inflacja jest na wysokim poziomie, dochodzi do deprecjacji własnej waluty w stosunku do walut partnerów handlowych. Często takiemu zjawisku towarzyszą wyższe stopy procentowe. Przykładowo jeżeli tempo inflacji w krajach strefy euro będzie wyższe niż w Polsce, kurs EUR/ PLN będzie maleć. Złoty będzie tracił na wartości mniej niż euro, a rynek odzwierciedli to w notowaniach waluty (Poradnik-forex.com, 2012).

- Produkt Krajowy Brutto - jest jednym z istotniejszych wskaźników ekonomicznych wpływających na cenę waluty. Przedstawia on sumę wszystkich dóbr i usług wytworzonych na terenie danego kraju w określonym czasie. Raporty zawierające dane o PKB dostarczają informacji o sytuacji gospodarczej państwa. Jeżeli PKB rośnie, oznacza to, że gospodarka danego kraju rozwija się oraz wzmacnia walutę. Natomiast spadek PKB oznacza recesję, która wpływa na osłabienie waluty (akademiaforex.com, 2013). 
- Poziom bezrobocia - również ma wpływ na kursy walutowe. Malejące bezrobocie przyczynia się do poprawy sytuacji gospodarczej krajów oraz tempa wzrostu gospodarczego, skutkuje to umocnieniem się waluty danego kraju. Efekt odwrotny występuje w sytuacji, gdy bezrobocie rośnie - wtedy może dojść do osłabienia waluty krajowej (kalkulator.pl, 2017).

- Bilans handlowy - występuje obustronna zależność pomiędzy obrotami handlowymi a kursami walut. Zmiany struktury oraz salda bilansu handlowego wpływają na kursy walut, z drugiej strony cena waluty wpływa na wielkość eksportu oraz importu danego kraju. Często występuje zależność pomiędzy wzrostem importu a słabnięciem waluty i na odwrót. Spowodowane jest to tym, że przedsiębiorcy muszą sprzedać walutę krajową na rzecz waluty obcej, by móc kupić dobra zza granicy. Przeciwnie dzieje się, gdy występuje nadwyżka handlowa - wtedy podmioty zagraniczne chętniej kupują walutę danego kraju, aby dokonać zakupu dóbr eksportowanych (Money.pl, 2013).

Zmienność kursów walutowych uwarunkowana jest bardzo wieloma czynnikami. Główną rolę odgrywają wskaźniki makroekonomiczne. Istotny wpływ na kursy walut mają także czynniki geopolityczne, psychologiczne czy spekulacyjne.

\subsection{Analiza techniczna, czyli jak analizować kursy walut}

Analiza techniczna pozwala prognozować przyszłe kursy walut na podstawie danych historycznych. Zakłada, że rynek w określonych sytuacjach oraz momentach zachowuje się podobnie. Daje to możliwość przewidywania przyszłych kursów walut w celu minimalizowania strat oraz maksymalizowaniu zysków (forex.pl, 2017).

Kluczowy w analizie technicznej jest trend, czyli kierunek, w jakim porusza się rynek. W zależności od tego, jak na wykresie układają się kolejne szczyty i dołki cenowe, możliwe jest wyróżnienie kilku rodzajów trendów:

- Trend wzrostowy - każdy kolejny dołek cenowy położony jest coraz wyżej.

Wykres 1 . Trend wzrostowy

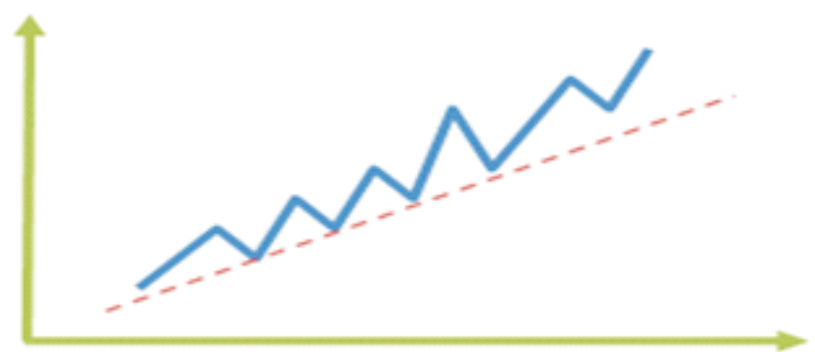

Źródło: opracowanie własne 
- Trend spadkowy - każdy kolejny szczyt cenowy położony jest coraz niżej.

Wykres 2. Trend spadkowy

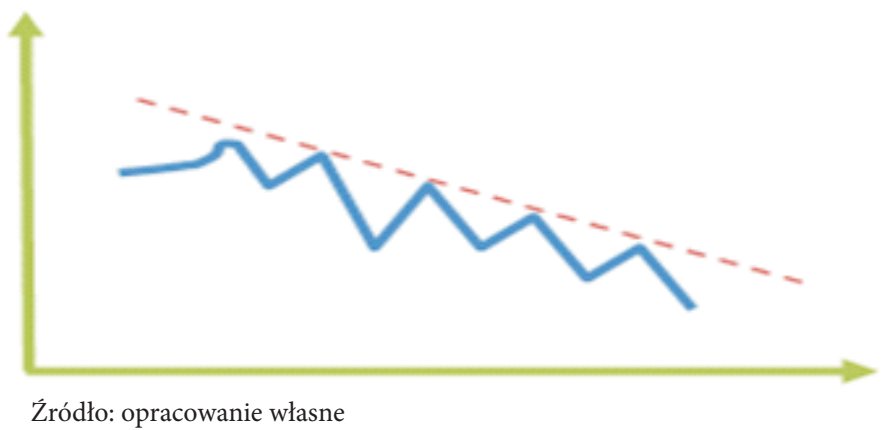

- Trend horyzontalny (boczny) - seria dołków i szczytów ułożonych przesuwających się w bok.

Wykres 3. Trend horyzontalny (boczny)

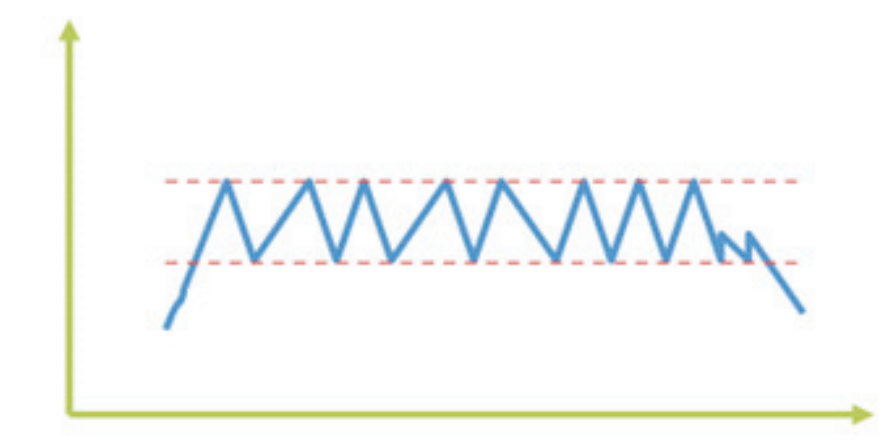

Źródło: opracowanie własne

Analiza techniczna polega przede wszystkim na rozpoznawaniu trendów, wykorzystywaniu już istniejących oraz rozpoznawaniu momentów, w których trend się odwróci.

\section{Zarządzanie ryzykiem}

Forex jest największym rynkiem finansowym na świecie, z codziennymi transakcjami wartymi kilka bilionów dolarów. Zatem występuje na nim potencjał dużych zysków, ale również ogromnych strat. W celu zmniejszenia prawdopodobieństwa 
utraty kapitału powinno się znać pewne środki ostrożności i ich przestrzegać (Galant, 2012, s. 329-332):

- Jedną z ważniejszych zasad zarządzania ryzykiem na Forexie jest inwestowanie tylko tylu pieniędzy, ile można stracić bez utraty komfortu dotychczasowego życia. To znaczy, że zamiast „iść na całość”, dużo lepiej jest ostrożniej i z głową zarządzać kapitałem.

- Emocjonalna strategia zarządzania ryzykiem - inwestorzy często wpadają w pułapkę i zbyt długo zwlekają z zamknięciem otwartej pozycji, licząc na to, że kurs zmieni kierunek. Trader powinien kontrolować swoje emocje, w miarę szybko zrozumieć swój błąd i zamknąć przynoszącą straty pozycję, by nie tracić więcej pieniędzy.

- Zlecenie STOP-LOSS jest podstawowym narzędziem umożliwiającym redukcję utraty kapitału. Pozwala automatycznie zamknąć pozycję w przypadku, gdy kurs spadnie do akceptowalnego przez Tradera poziomu.

- Korzystanie z dźwigni na rozsądnym poziomie. Wielkość pozycji, jaką inwestor zdecyduje się otworzyć, przekłada się na poziom ryzyka, na który będzie narażony. Im większa pozycja, tym większe ryzyko. Brokerzy kuszą dużymi dźwigniami, ale należy zachować umiar, gdyż otwarcie zbyt dużej pozycji w stosunku do wartości depozytu zmniejsza poduszkę bezpieczeństwa, która chroni przed rutynowymi, niekorzystnymi ruchami kursów. Powinno się korzystać z dźwigni, która odpowiada przyjętej strategii.

- W celu ograniczenia ryzyka związanego z wpływem emocji na podejmowane decyzje zaleca się grać $\mathrm{z}$ wcześniej przygotowanym kompletnym planem. Zawarcie w nim wszystkich istotnych elementów gry, zaczynając od poziomu i czasu wejścia na rynek, aż po wyjście z niego i zamknięcie pozycji, może zaoszczędzić inwestorowi dużo pieniędzy oraz spokoju.

- Bycie na bieżąco. Informacja jest podstawowym czynnikiem mającym wpływ na kursy walut, zatem ważne jest, by być na bieżąco z wydarzeniami, które rozgrywają się w gospodarce. Przygotowanie się na nadchodzące wydarzenie może uchronić inwestora przed stratą lub też przynieść mu zyski.

- Systematyczne realizowanie zysków jest jednym z pewniejszych sposobów ograniczenia ryzyka. Gdy dana pozycja wygeneruje zysk i zostanie zamknięta w całości lub w części, przestaje być narażona na ekspozycje na niesprzyjające zachowania rynku. Nigdy nie straci się wszystkiego, jeżeli zyski będą realizowane systematycznie.

- Dywersyfikacja jest działaniem mającym na celu ograniczanie strat poprzez inwestowanie kapitału na kilku obszarach. Dywersyfikację wykonuje się w nadziei, że ewentualne spadki jednego aktywa zostaną pokryte przez zyski $\mathrm{z}$ innego. Dywersyfikacja pozwala ograniczać straty, ale także zmniejsza prawdopodobieństwo uzyskania najwyższego zysku (Sławiński, 2006, s. 62). 


\section{Podsumowanie}

Forex jest bardzo ciekawym rynkiem, na którym handluje się walutami różnych krajów przez całą dobę z wykorzystaniem dźwigni finansowej. Wyróżnia się tym na tle innych rynków, dzięki czemu nieustannie przyciąga nowych uczestników chcących pomnożyć swoje oszczędności. Trzeba jednak pamiętać, że handel walutami na Forexie nie jest zajęciem łatwym, gdyż statystycznie $80 \%$ użytkowników traci tam swoje pieniądze. Osiągnięcie sukcesu zależy od ogromnej wiedzy uczestników, doświadczenia oraz zaangażowania.

Celem artykułu było zaprezentowanie istoty Forexu oraz przykładowych sposobów radzenia sobie z ryzykiem, w celu ograniczenia strat i zwiększenia prawdopodobieństwa zysków. Uważam, że sama wiedza teoretyczna nie wystarczy, by uchronić się przed ryzykiem strat. W przypadku spekulowania bardzo duży wpływ na podejmowane decyzje mają emocje, zatem przed przystąpieniem do handlu walutami dobrze jest się zapoznać z elementami psychologii inwestowania. Zaleca się rozpoczęcie przygody z Forexem np. od wersji demo, na której korzysta się z wirtualnych pieniędzy, lub granie na niewielkich kwotach. Dopiero wraz z upływem czasu i ze zdobytym doświadczeniem powinno się myśleć o spekulowaniu na poważnie. Jak mawiał Warren Buffett: „Ryzyko bierze się z niewiedzy o tym, co robisz", tak więc aby ryzyko strat zostało zminimalizowane, powinniśmy kształcić się i nieustanie zdobywać wiedzę o tym, co robimy.

\section{LITERATURA}

[1] Galant M., Forex dla bystrzaków, Gliwice, Helion, 2012.

[2] Kochan K., Forex w praktyce, Gliwice, Helion, 2006.

[3] SŁAWIŃsKi A., Rynki finansowe, Warszawa, PWE, 2006.

[4] SтоlaRCzyк B., Czynniki wplywające na wartość waluty ze szczególnym uwzględnieniem polskiego złotego, Sopot, Uniwersytet Gdański, 2015.

\section{NETOGRAFIA}

[1] http://www.najlepszeplatformyforex.pl/blog/uczestnicy-rynku-forex/ (7.05.2017).

[2] https://admiralmarkets.pl/education/articles/forex-basics/zarzadzanie-ryzykiem-w-handlu-na-forex (7.05.2017).

[3] http://www.forex.pl/edukacja/baza-wiedzy/analiza-techniczna (7.05.2017).

[4] https://www.poradnik-forex.com/2012/10/26/czynniki-wp\%C5\%82ywaj\%C4\%85ce-na-kursywalut-cz\%C4\%99\%C5\%9B\%C4\%87-1/ (7.05.2017).

[5] http://www.money.pl/sekcja/co-wplywa-na-kursy-walut/co;wplywa;na;kursy;walut;zobacz;raport,139,1,1302411.html (7.05.2017).

[6] http://akademiaforex.com/jak-pkb-wplywa-na-cene-waluty/ (7.05.2017).

[7] http://www.kalkulator.pl/inwestycje-waluty-wplywa-kurs-walutowy/ (7.05.2017).

[8] http://www.money.pl/sekcja/co-wplywa-na-kursywalut/co;wplywa;na;kursy;walut;zobacz; raport,139,4,1302411.html (7.05.2017). 
